\title{
Volatile component change in whey protein concentrate during storage investigated by headspace solid-phase microextraction gas chromatography
}

\author{
Issa JAVIDIPOUR, Michael C. QIAN* \\ Department of Food Science and Technology, Oregon State University, \\ Corvallis, Oregon, 97330, USA
}

\begin{abstract}
Whey protein concentrate (WPC) is a nutritious ingredient and has gained popularity to be used in many traditional and novel food products. It typically has a shelf-life of 9 to 18 months when stored at room temperature. Fresh manufactured WPC could have a bland or slightly dairy, whey flavor. However, recognizable off-flavor can be developed during storage and this off-flavor becomes one of the major factors limiting its application in delicate formula. To understand the off-flavor development during the storage, WPC 80 and Instantized WPC 80 samples were stored at 35,40 and $45{ }^{\circ} \mathrm{C}$ for a period of 15 weeks. Selected volatile compounds including dimethyl disulfide, pentanal, hexanal, heptanal, 2-heptanol, 2-octanone, octanol, 1-octen-3-ol, 1-nonanol and 2-nonanol were analyzed using headspace solid-phase microextraction gas chromatography. The results showed that the concentrations of most of these compounds considerably increased during storage, especially when stored at $45^{\circ} \mathrm{C}$. Instantized WPC showed higher lipid oxidation compounds than regular WPC while removal of oxygen reduced their formation.
\end{abstract}

whey protein concentrate / volatile formation / solid phase microextraction / gaschromatography

摘要 - 顶空固相微萃取-气相色谱法研究乳清浓缩蛋白咜藏期间挥发性组分的变化。乳清 浓缩蛋白 (WPC) 作为重要的营养添加剂在食品工业中广泛使用。乳清浓缩蛋白在室温下的 货架期为 9-18 个月。新生产出的乳清浓缩蛋白无味或有轻微的牛奶味和乳清味, 然而乳清 浓缩蛋白在䛎藏过程中会产生明显的异味, 这种异味限制了其在一些特殊配方食品中的应 用。为了研究在它藏过程中异味的形成, 将 WPC 80 和速溶WPC 80 蛋白粉分别在 $35-40$ $45^{\circ} \mathrm{C}$ 下贮藏 15 周。采用顶空固相微萃取_气相色谱法分析了乳清蛋白粉样品中异味成分 二甲基二硫醚、戊醛、己醛、庚醛、2-庚醇、2-辛酮、辛醇、1-辛烯-3-醇、1-壬醇和 2-壬 醇。结果表明, 在陉藏期间多数化合物浓度显著地增加, 尤其在 $45^{\circ} \mathrm{C}$ 下陉藏时这些异味化合 物浓度显著地增加。速溶乳清浓缩蛋白比普通乳清浓缩蛋白的异味重, 而脱氧包装可以有效 地降低异味化合物的形成。

乳清浓缩蛋白 / 异味的形成 / 固相微萃取 / 气相色谱

*Corresponding author (通讯作者): Michael.qian@oregonstate.edu 


\begin{abstract}
Résumé - Variation des composés volatils dans des concentrés de protéines de lactosérum au cours du stockage suivie par chromatographie en phase gazeuse après microextraction en phase solide. Le concentré de protéines de lactosérum (CPL) est un ingrédient nutritif de plus en plus utilisé dans de nombreux produits alimentaires traditionnels ou nouveaux. Conservé à température ambiante, il a une durée de vie de 9 à 18 mois. Juste après fabrication, le CPL a une flaveur fade ou légèrement laitière de lactosérum. Cependant des défauts de flaveur peuvent se développer au cours du stockage et devenir un facteur limitant majeur pour son utilisation ultérieure dans des formules délicates. Pour comprendre le développement de défauts de flaveur au cours du stockage, des échantillons de CPL 80 et de poudre de CPL 80 (poudre sous atmosphère d'oxygène ou non), ont été stockés à 35,40 et $45^{\circ} \mathrm{C}$ sur une période de 15 semaines. Des composés volatils sélectionnés (disulfure de diméthyl, pentanal, hexanal, heptanal, 2-heptanol, 2-octanone, octanol, 1-octen-3-ol, 1-nonanol et 2-nonanol) ont été analysés par chromatographie en phase gazeuse après microextraction en phase solide. Les résultats ont montré que les concentrations de la plupart de ces composés augmentaient au cours du stockage, surtout à $45^{\circ} \mathrm{C}$. Il se formait plus de composés d'oxydation des lipides dans les poudres de CPL que dans le CPL, cependant plus faiblement en l'absence d'oxygène.
\end{abstract}

concentré de protéines de lactosérum / composé volatil / microextraction en phase solide / chromatographie en phase gazeuse

Abbreviations: $W P C$ : regular $80 \%$ whey protein concentrate; $H S$ : head space; SPME: solid phase microextraction; $G C$ : gas chromatography; $M S$ : mass spectrometry; HPLC: high performance liquid chromatography; FID: flame ionization detector; $R I$ : retention index.

\section{INTRODUCTION}

Whey protein concentrate (WPC) provides a rich protein source for fortification of many products including cereals, beverages, infant formula and sports supplements because of its high nutritional value [15]. In addition to the nutritional benefits, WPCs are widely used as functional ingredients to provide emulsifying, gelation, thickening, foaming and water-binding properties of food products [10]. However, whey protein concentrate typically has a "whey" flavor. As flavor is one of the most important factors affecting consumer choice and acceptance of dairy products [6], much research has been focused on the understanding the chemical nature of this whey offflavor [13, 15, 16, 21, 22].

WPC has been shipped globally and typically has a shelf-life of 9 to 18 months. Significant amount of off-flavor can be developped during the transportation and storage. The off-flavor development during storage is complicated, many chemical reactions including lipid oxidation, Maillard browning reactions [13] and amino acid degradation [12] can take place. Many factors can affect kinetics of these reactions, leading to the formation of different off-flavor compounds [19]. Aldehydes, ketones, alcohols and volatile sulfur compounds have been identifed as the most important off-flavor compounds formed during storage of WPC $[8,13]$.

Solid phase micro-extraction is a convenient technique to extract volatile compounds from complicated matrix. The technique relies on the absorption or adsorption of analytes onto the fiber and subsequently desorbed into an analytical instrument such as gas chromatography (GC), GC-mass spectrocopy (MS), high performance liquid chromatography (HPLC) or HPLC-MS [4, 5]. By selection the suitable internal standards, headspace SPME technique can be reliably used to quantify volatile off-flavor compounds in dairy matrix [20]. The objective of this study was to quantify the volatile compounds in WPC by HS-SPME-GC and study the effect of different storage temperature and presence of oxygen 
on their formation in regular and instantized WPCs.

\section{MATERIALS AND METHODS}

\subsection{Materials}

\subsubsection{Chemicals}

2-Methylpentanal, pentanal, heptanal 2-methyl-3-heptanone, octanol, 4-octanol, 2-heptanol, 1-octen-3-ol, nonanol, 2-nonanol and isopropyl disulfide were purchased from Aldrich Chemical Co. (Milwaukee, WI, USA); hexanal was purchased from Sigma Co. (St. Louis, MO, USA); 2-octanone was from Fluka Chemical Corp. (Milwaukee, WI, USA); and, dimethyl disulfide was from TCI America (Portland, OR, USA).

\subsubsection{WPC samples}

Freshly manufactured regular WPC80 and Instantized WPC80 were donated from WPC manufacturer in California, USA. The liquid whey from Cheddar and Monterey Jack cheese manufacturing was concentrated using membrane filtration technique and spray-dried. Lecithin was used in the instantization process in single pass on a MSD dryer (Multi-Stage Dryer). The instantized WPC was agglomerated. The samples were kept frozen at $-20^{\circ} \mathrm{C}$ upon arrival and used within 6 months in this study. One $\mathrm{kg}$ of each of regular WPC80, instantized WPC80 were placed in closed glass jars and stored at 35, 40 and $45^{\circ} \mathrm{C}$ in dark in conventional ovens for 15 weeks. Another instantized WPC80 sample was carefully flushed with argon to remove oxygen and kept at the same conditions. Samples were taken in 3 weeks intervals through the storage period. Volatile compounds in WPCs were analyzed by HS-SPME-GC.

\subsection{Methods}

\subsubsection{HS-SPME-GC analysis}

A 2-cm (50/30 $\mu \mathrm{m}$ divinylbenzene /carboxen/polydimethylsiloxane) SPME fiber (Supelco Co., Bellefonte, PA, USA) was used for the extraction of volatile compounds. The fiber was conditioned in a $\mathrm{GC}$ injection port at $270^{\circ} \mathrm{C}$ for $1 \mathrm{~h}$ before use. One and half of $g$ of WPC sample was dissolved in $6 \mathrm{~g}$ volatile-free (boiled for $30 \mathrm{~min}$ ) deionized water in a $20 \mathrm{~mL}$ glass vial, and an internal standard solution $(0.1 \mathrm{~g})$ was added. The sample mixture was equilibrated at $45^{\circ} \mathrm{C}$ for $5 \mathrm{~min}$ and extracted at the same temperature for $1 \mathrm{~h}$ with stirring using a SPME autosampler (Varian, Walnut Creek, CA, USA). After the extraction, the volatiles were desorbed in the injection port of a Varian's CP$3800 \mathrm{GC}$ equipped with a flame ionization detector (Varian). The injector temperature was set at $250^{\circ} \mathrm{C}$ and splitless injection mode was used for $5 \mathrm{~min}$. The samples were analyzed on a DB-wax column $(30 \mathrm{~m} \times 0.32 \mathrm{~mm}$ i.d., $0.25 \mu \mathrm{m}$ film thickness, J\&W Scientific, Folsom, CA, USA). Nitrogen was used as the carrier gas at a constant flow rate of $2 \mathrm{~mL} \cdot \mathrm{min}^{-1}$. The oven temperature was programmed at $35^{\circ} \mathrm{C}$ for a hold of $8 \mathrm{~min}$, and increased to $150^{\circ} \mathrm{C}$ at a rate of $4{ }^{\circ} \mathrm{C} \cdot \mathrm{min}^{-1}$, then increased to $230^{\circ} \mathrm{C}$ at a rate of $20^{\circ} \mathrm{C} \cdot \mathrm{min}^{-1}$ and hold at the final temperature for $20 \mathrm{~min}$. The FID detector temperature was $270^{\circ} \mathrm{C}$. All the samples were analyzed in triplicate, and the same fiber was used for the entire experiment.

\subsubsection{Gas chromatography-mass spectrometry}

The mass spectra of WPC samples were obtained by using an Agilent 6890 GC equipped with a 5793 quadrulope mass analyzer detector (Agilent Technologies, Inc. Santa Clara, CA, USA). Separation was 
performed on a DB-wax column $(30 \mathrm{~m} \times$ $0.32 \mathrm{~mm}$ i.d., $0.25 \mu \mathrm{m}$ film thickness, J\&W Scientific). The same oven program as GC-FID analysis was performed. Helium was used as the carrier gas at a flow rate of $1 \mathrm{~mL} \cdot \mathrm{min}^{-1}$. The injector temperatures was $250^{\circ} \mathrm{C}$. Electron impact ionization was used at a voltage of $70 \mathrm{eV}$ and $\mathrm{m} / \mathrm{z}$ scan range of 35 to 350 was collected at $4.51 \mathrm{scan} \cdot \mathrm{s}^{-1}$. The instrument control of data analysis was performed using enhanced Chemstation software (Agilent Technologies, Inc.). The volatile compounds in WPC were identified by comparing mass spectra and retention index with those of authentic compounds.

\subsubsection{Quantitative analysis}

Standard stock solution was prepared in $8 \mathrm{~g}$ methanol containing $0.06 \mathrm{~g}$ each of dimethyl disulfide, pentanal, hexanal, heptanal, 2-heptanol, 2-octanone, octanol, 1-octen-3-ol, 1-nonanol and 2-nonanol. Aliquots of the diluted standard stock solutions were used to spike $7.5 \mathrm{~g}$ of volatile-free deionized water to concentrations of $1.25,5,10,25,50,100,200$, 500 and $2000 \mathrm{ppb}$. An aliquot internal standard solution containing 2-methylpentanal, 2-methyl-3-heptanone, isopropyl disulfide and 4-octanol was then added to yield a final concentration of 500, 100, 250 and $50 \mathrm{ppb}$, respectively. The standard solution was equilibrated at $45^{\circ} \mathrm{C}$ for $5 \mathrm{~min}$ and extracted for $1 \mathrm{~h}$ by using SPME and analyzed by GC-FID. Calibration curves for the volatile compounds were constructed by applying linear regression analysis on the concentration ratio (concentration of compound/concentration of internal standard) and peak area ratio (area of compound/area of internal standard). Triplicate analysis was performed at each concentration level. The concentrations of a volatile compounds in WPC samples were calculated based on the calibration curve of the corresponding compounds (Tab. I).

\section{RESULTS AND DISCUSSION}

Previous researches demonstrated that lipid oxidation was probably the most important contributor for WPC off-flavor development during storage [11, 15, 21]. A wide range of saturated and unsaturated aldehydes have been identifed to be associated with lipid oxidation in WPC. The main saturated aldehydes were 2-methylbutanal, 3-methylbutanal, pentanal, hexanal, heptanal, octanal, nonanal, decanal, dodecanal and tridecanal. In addition, many unsaturated aldehydes, including 2-heptenal, 2-octenal, 1-nonenal, 2-nonenal, 2-decenal, 1-undecenal, 2,4-heptandienal, 2,4-nonadienal, 2,6-nonadienal, and 2,4-decadienal have been hypothesized to contribute to the chardboard, stale and oxidized off-flavor in whey and whey protein concentrate.

Ten volatile compounds covering the classes of aldehyde, ketone, alcohol and sulfur-containing compounds were selected for quantification. The concentrations of pentanal, heptanal and hexanal were monitored during the storage of WPC samples. Pentanal had low initial content, and its concentration did not change much during the storage (ranged between 21 and $35 \mathrm{ppb}$ ). Increasing storage temperature and flush with argon had no obvious impact on pentanal concentration. Hexanal was the second most abundant volatile compound in WPC and its concentration increased with storage time and temperature (Fig. 1). The hexanal content increased 2.5 times during the 12 weeks of storage period for most of the samples, and reached to $2500 \mathrm{ppb}$ for instantized sample stored at $45^{\circ} \mathrm{C}$. However, there was a decreasing trend in hexanal concentration after 12 weeks up to the 15 weeks 
Table I. Regression equations for whey protein concentrate flavor compounds spiked in volatile-free deionized water.

\begin{tabular}{lllllr}
\hline Compound & Internal standard & $\begin{array}{l}\text { Regression } \\
\text { equation }\end{array}$ & $\mathrm{R}^{2}$ & $\begin{array}{c}\text { Calibration } \\
\text { limit }(\mathrm{ppb})^{2}\end{array}$ \\
\hline 1 & Dimethyldisulfide & Isopropyldisulfide & $\mathrm{y}=0.005 \mathrm{x}$ & 0.8888 & 31.9 \\
2 & Hexanal & 2-Methypentanal & $\mathrm{y}=0.3937 \mathrm{x}$ & 0.9962 & 1.6 \\
3 & Heptanal & 2-Methyl-3-heptanone & $\mathrm{y}=0.3053 \mathrm{x}$ & 0.9959 & 1.6 \\
4 & 2-Octanone & & $\mathrm{y}=0.01262 \mathrm{x}$ & 0.9969 & 6.5 \\
5 & 2-Heptanol & 4-Octanol & $\mathrm{y}=0.0399 \mathrm{x}$ & 0.9219 & 6.0 \\
6 & 1-Octen-3-ol & $\mathrm{y}=0.1211 \mathrm{x}$ & 0.9963 & 14.5 \\
7 & 2-Nonanol & $\mathrm{y}=0.0669 \mathrm{x}$ & 0.9971 & 64.6 \\
8 & Octanol & $\mathrm{y}=0.001 \mathrm{x}$ & 0.9985 & 1.5 \\
9 & Nonanol & & & \\
\hline
\end{tabular}

${ }^{1} \mathrm{y}$ : Compound area/internal standard area; $\mathrm{x}$ : compound concentration/internal standard concentration.

${ }^{2}$ Calculated as the concentration that gives a signal-to-noise ratio of 10 .

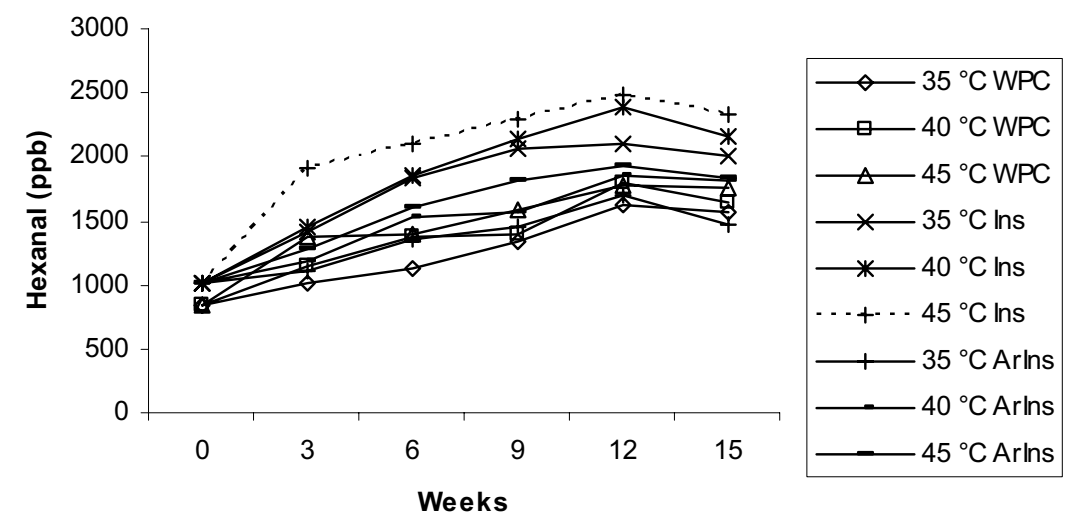

Figure 1. Hexanal development stored at different temperatures.

* Triplicated analysis for each sample with relative standard deviation $<10 \%$.

of storage. Instantized WPC showed the highest hexanal formation in all storage temperatures. Since hexanal is known to be formed by lipid oxidation [12], the phospholipids used in the instantizing process of WPC could increase the residual lipid content, and contributed to this elevated oxidation. In addition, industrial lecithin used as the instantizing agent may contain soybean oil, and the unsaturated fatty acids in soyben oil may further contribute to the formation of hexanal. As expected, flushing the sample with argon will reduce the oxygen content, thus reduce lipid oxidation. The hexanal levels were greatly reduced in argon-flushed instantized WPC. The hexanal level in argon-flushed instantized WPC at $40^{\circ} \mathrm{C}$ was reduced to a level close to that in the regular WPC stored at the same temperature. Hexanal has been reported to be one of the major oxidation products in WPC at accelerated storage conditions [7] and its concentration increased to $1430 \mathrm{ng} \cdot \mathrm{g}^{-1}$ when stored at $60^{\circ} \mathrm{C}$ for 6 days [9]. Similar trend was observed for heptanal 


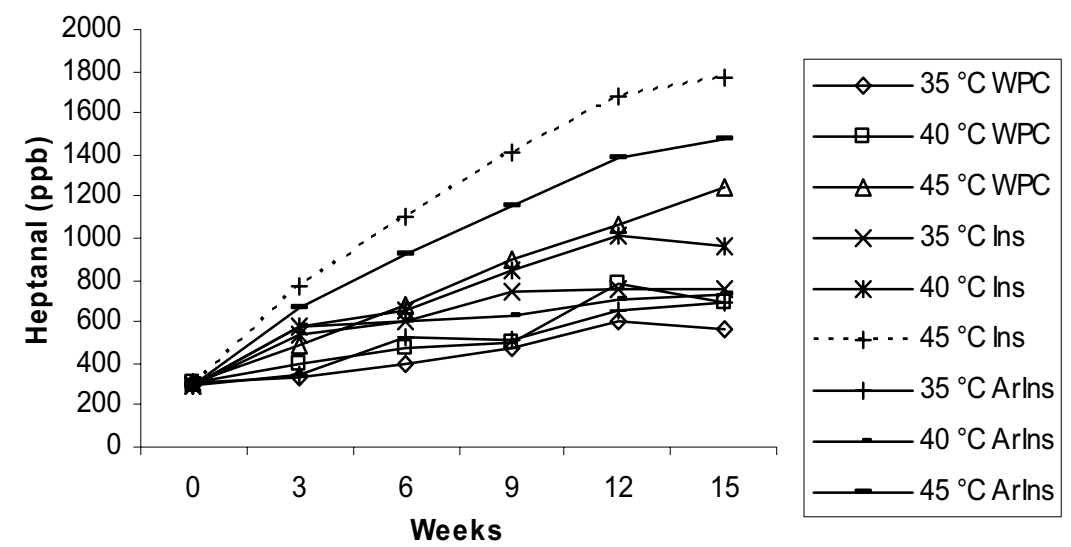

Figure 2. Heptanal development stored at different temperatures.

* Triplicated analysis for each sample with relative standard deviation $<10 \%$.

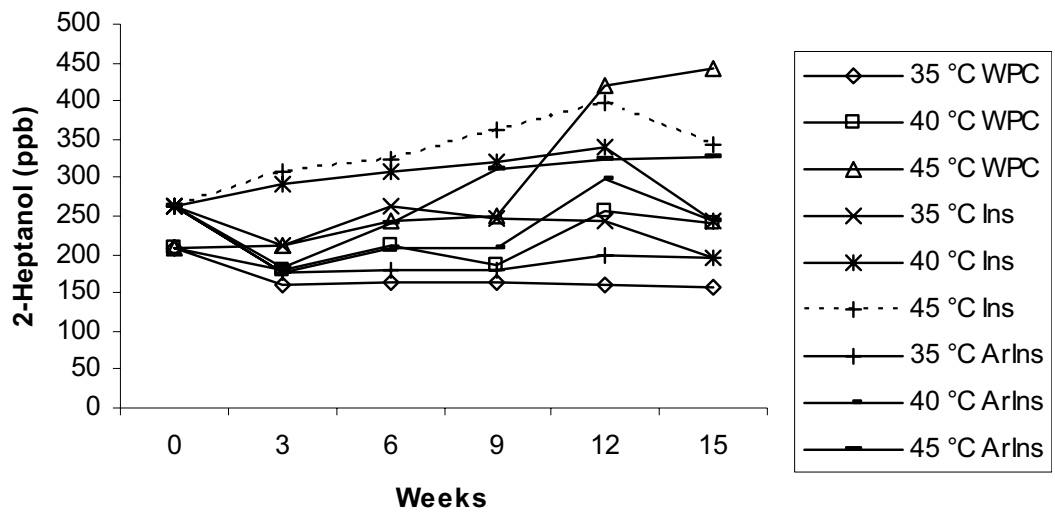

Figure 3. 2-Heptanol development stored at different temperatures.

* Triplicated analysis for each sample with relative standard deviation $<10 \%$.

formation (Fig. 2). The concentration of heptanal increased with the storage temperature and time, and argon flush reduces its formation. However, the storage temperature seemed to play a much bigger role than for hexanal formation. Heptanal levels were the highest when samples were stored at $45^{\circ} \mathrm{C}$. Hexanal and heptanal have very low sensory threshold of $4.5 \mu \mathrm{g} \cdot \mathrm{kg}^{-1}$ and $3 \mu \mathrm{g} \cdot \mathrm{kg}^{-1}$ [17], respectively, the high concentrations of hexanal and heptanal in WPC indicated that they will likely contribute to the off-flavor of WPC, particularly to the WPCs after storage.

Although most alcohols have high sensory thresholds and are not important to off-flavor formation in WPCs, some alcohols, especially unsaturated alcohols, could be very important to off-flavor formation. The formation of 2-heptanol, 1-octanol, 1-octen-3-ol, 1-nonanol and 2-nonanol were monitored during WPC storage. 2-Heptanol showed 


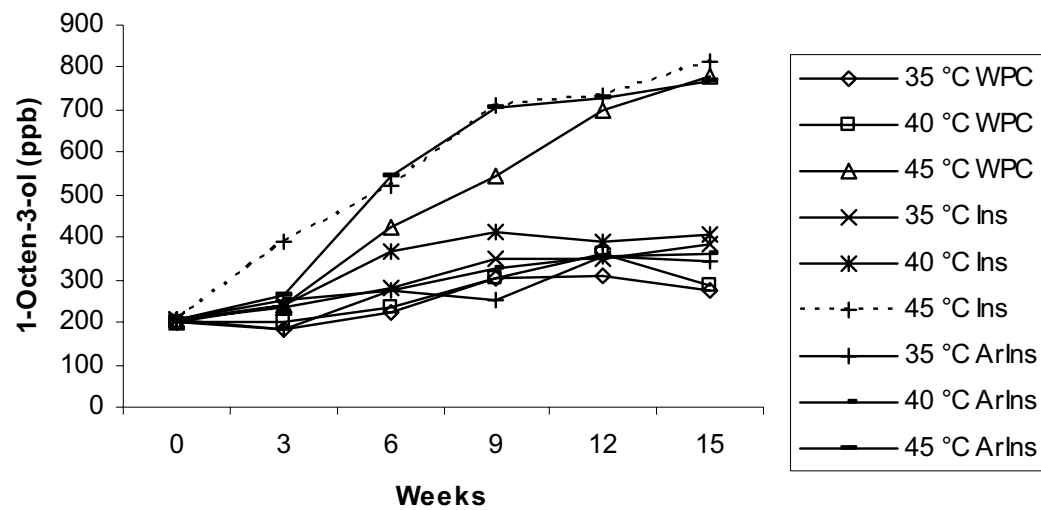

Figure 4. 1-Octen-3-ol development stored at different temperatures.

* Triplicated analysis for each sample with relative standard deviation $<10 \%$.

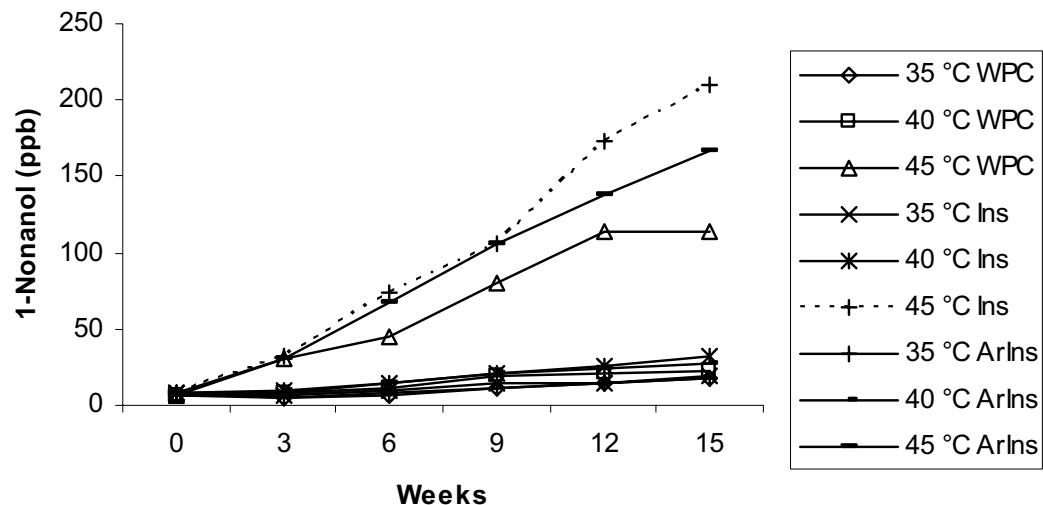

Figure 5. 1-Nonanol development stored at different temperatures.

${ }^{*}$ Triplicated analysis for each sample with relative standard deviation $<10 \%$.

a slight increase when the samples were stored at higher temperature, especially for instantized WPC. However, this increasing trend was not obvious when the samples were stored at $35^{\circ} \mathrm{C}$ (Fig. 3). 1-Octanol was found at low concentrations (16$35 \mathrm{ppb})$ in the WPC samples. Similar to 2-heptanol, the concentration of 1-octanol did not increase much as the storage temperature and time increased (data not shown). In contrast, obvious increasing trend was observed for 1-octen-3-ol, 1-nonanol and 2-nonanol during storage (Figs. 4, 5 and 6), and dramatic increase was observed at $45^{\circ} \mathrm{C}$ regardless of the sample. 1-Octen-3-ol was the most abundant alcohol in WPC samples and its concentration increased from $200 \mathrm{ppb}$ to $800 \mathrm{ppb}$ after 15 weeks storage at $45^{\circ} \mathrm{C}$. Concentration of 2-nonanol increased approximately 10 to 20 fold after storage at $40^{\circ} \mathrm{C}$ and $45^{\circ} \mathrm{C}$, respectively. Alcohols have also been reported as products of lipid oxidation [9].

Only 2-octanone was quantified in this study although many other ketones such as 2-nonanone, 1-octen-3-one and 3-octen-2-one have been identified in whey and WPC products to contribute to offflavor $[9,11,15,21]$. Increasing temperature 


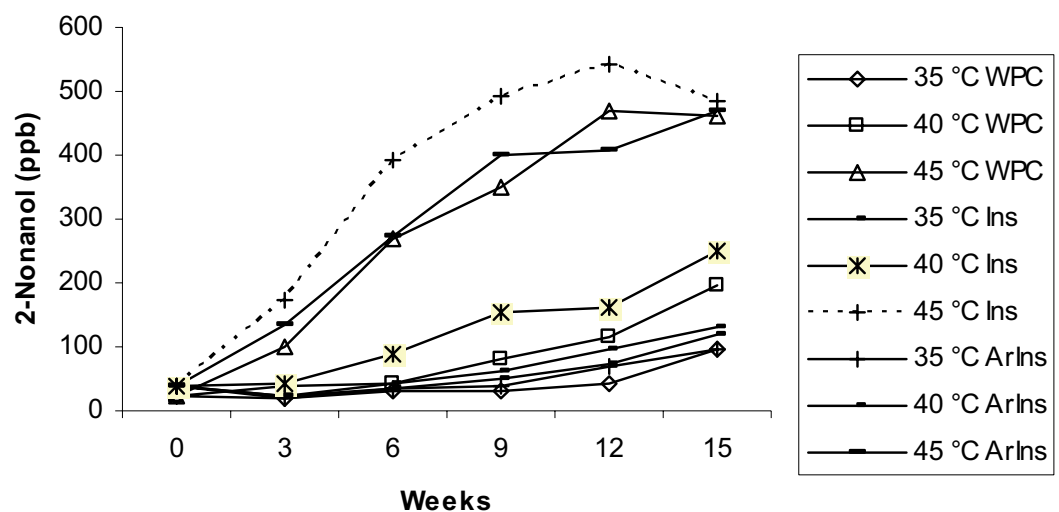

Figure 6. 2-Nonanol development stored at different temperatures.

* Triplicated analysis for each sample with relative standard deviation $<10 \%$.

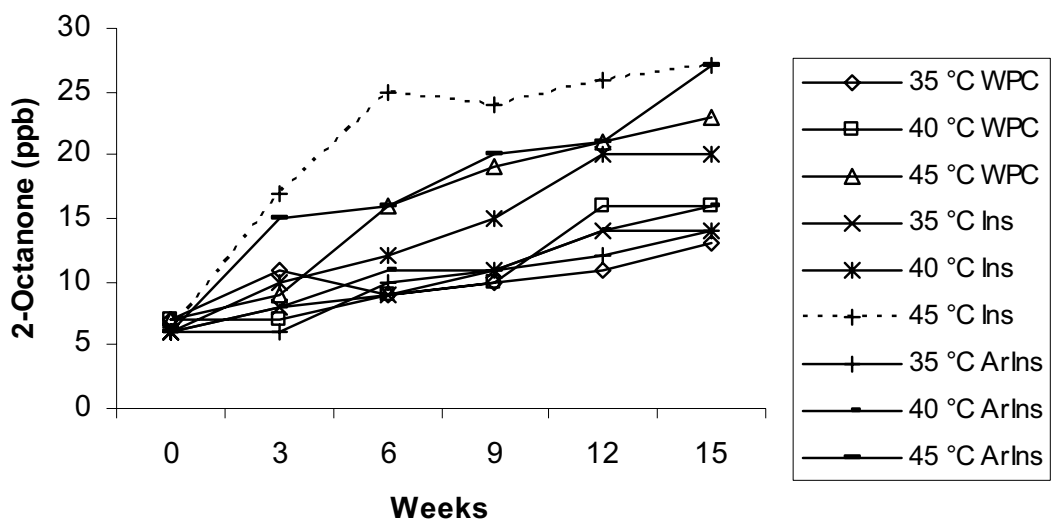

Figure 7. 2-Octanone development stored at different temperatures.

* Triplicated analysis for each sample with relative standard deviation $<10 \%$.

and storage time slightly increased the formation of 2-octanone (Fig. 7). In general, methyl ketones represent a group of flavor compounds strongly associated with stale, cardboard or metallic flavors in many spray-dried dairy products [18].

Many sulfur-containing compounds have been identified to contribute to the off-flavor of whey and WPC $[11,15,21]$. Dimethyl disulfide was the most abundant volatile compounds identifed in stored WPC samples. When stored below $40{ }^{\circ} \mathrm{C}$, increasing storage time slightly increased the formation of dimethyl disulfide (Fig. 8). When the temperature increased from $35^{\circ} \mathrm{C}$ to $40^{\circ} \mathrm{C}$, slight increase of dimethyl disulfide formation was observed. Temperature increase from $40{ }^{\circ} \mathrm{C}$ to $45^{\circ} \mathrm{C}$ induced a dramatic increase of dimethyl disulfide formation during storage. When the samples were stored over 12 weeks, the concentrations of dimethyl disulfide in WPCs stored at $45^{\circ} \mathrm{C}$ were more than 7 times of those stored at $40^{\circ} \mathrm{C}$. Lee et al. [9] also reported that the dimethyl disulfide was increased to over $2300 \mathrm{ng} \cdot \mathrm{g}^{-1}$ when WPC was stored at $60^{\circ} \mathrm{C}$ for 6 days. Sulfur-containing 


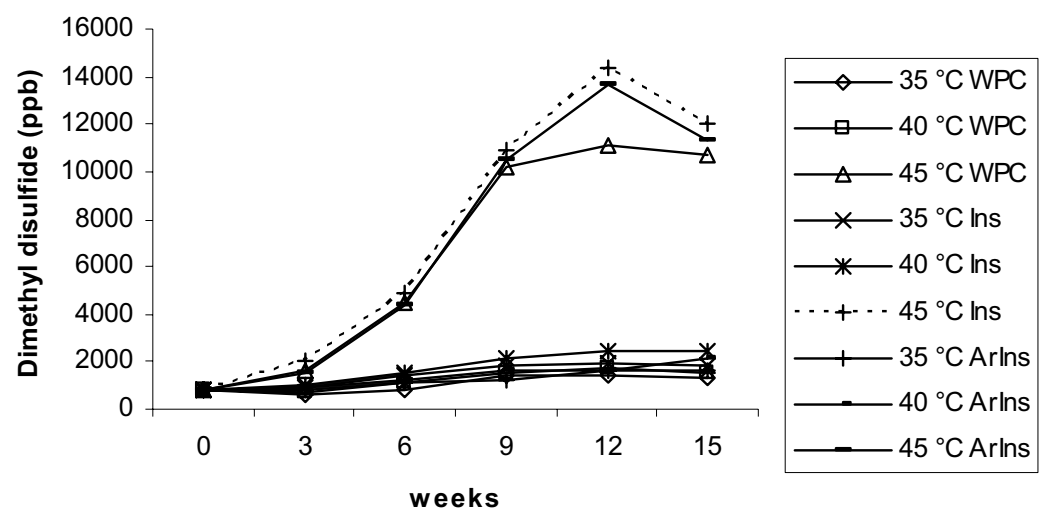

Figure 8. Dimethyl disulfide development stored at different temperatures.

${ }^{*}$ Triplicated analysis for each sample with relative standard deviation $<10 \%$.

compounds are generated from the oxidation of amino acids, methionine and cystein. Methionine and cystein can be degraded into methanethiol [1], oxidation of methanethiol can lead to the formation of dimethyl disulfide and dimethyl trisulfide [3, 7]. Calvo and De la Hoz [2] suggested that dimethyl disulfide may be formed from the release of the activated sulfydryl groups of $\beta$-lactoglobulin during the heat denaturation of whey proteins. Sulfur compounds often have very low sensory thresholds, and thus they contribute to the flavor or off-flavor of many food products, even at very low concentrations [14].

\section{CONCLUSION}

SPME is a convenient and sensitive technique for investigating the formation of volatiles in WPC during storage. In general, the concentration of volatile compounds increased with storage temperature and time. Instantized WPC had a higher off-flavor formation than regular WPC stored at all temperatures. Argon flush decreased the formation of volatile compounds. The effect of storage temperature on volatile formation in WPC was both temperature and compound dependent. For some compounds, dramatic increases of volatile formation were observed when the temperature was increased to $45^{\circ} \mathrm{C}$.

\section{REFERENCES}

[1] Bendall J.G., Aroma compounds of fresh milk from New Zealand cows fed different diets, J. Agric. Food Chem. 49 (2001) 48254832.

[2] Calvo M.M., De la Hoz L., Flavour of heated milks: a review, Int. Dairy J. 2 (1992) 69-81.

[3] Ferretti A., Flanagan V.P., Volatile constituents of whey powder subjected to accelerated browning, J. Dairy Sci. 54 (1971) 1764-1768.

[4] Kalua C.M., Bedgood J.D.R., Prenzler P.D., Development of a headspace solid phase microextraction-gas chromatography method for monitoring volatile compounds in extended time-course experiments of olive oil, Anal. Chem. Acta. 556 (2006) 407-414.

[5] Kataoka H., Lord H.L., Pawliszyn J., Application of solid-phase microextraction in food analysis, J. Chromatogr. A. 800 (2000) 35-62.

[6] Kim Y.D., Morr C.V., Dynamic headspace analysis of light activated flavor in milk, Int. Dairy J. 6 (1996) 185-193.

[7] Laye I.D., Karelskind D., Morr C.V., Dynamic headspace analysis of accelerated storage commercial whey protein concentrate using four absorbent traps, Milchwissenchaft 50 (1995) 268-272. 
[8] Lee Y., Effect of water activity on headspace volatile compounds in whey protein concentrate and other spray dried dairy products during accelerated storage, Ph.D. dissertation, Ohio State University, Columbus, 1993.

[9] Lee Y.B., Laye I., Kim Y.D., Morr C.V., Formation of volatile compounds in whey protein concentrate during elevated temperature storage as a function of water activity, Int. Dairy Technol. 6 (1996) 485-496.

[10] Lizarraga M.S., Vicin D.D.P., Gonzalez R., Rubiolo A., Santiago L.G., Rheological behaviour of whey protein concentrate and $\lambda$-carrageenan aqueous mixture, Food Hydrocoll. 20 (2006) 740-748.

[11] Mahajan S.S., Goddik L., Qian M.C., Aroma compounds in sweet whey powder, J. Dairy Sci. 87 (2004) 4057-4063.

[12] Mills O.E., Flavour of WC., in: Charalambous G. (Ed.), Food Flavours, Ingredients and Composition, Elsevier Science Publishers, Amsterdam, The Netherlands, 1993, pp. 139-149.

[13] Morr C.V., Ha E.Y.W., Off-flavors of whey protein concentrates: A Literature Review, Int. Dairy J. (1990) 1-11.

[14] Morr C.V., Ha E.Y.W., Whey protein concentrates and isolates: processing and functional properties, Critical Rev. Food Sci. 33 (1993) 431-476.

[15] Quach M.L., Chen X.D., Stevenson R.J., Headspace sampling of whey protein concentrate solutions using solid-phase microextraction, Food Res. Int. 31 (1999) 371-379.
[16] Russell T.A., Drake M.A., Gerard P.D., Sensory properties of whey and soy proteins, J. Food Sci. 71 (2006) 447-455.

[17] Rychlik M., Schieberle P., Grosch W., Compilation of odor thresholds, odor qualities and retention indices of key food odorants, Deutsche Forschungsanstalt für Lebensmittelchemie and Institut für Lebensmittelchemie der Technischen Universität München: Garching, Germany, 1998.

[18] Shiratsuchi H., Shimoda M., Imayoshi K., Noda K., Osajima Y., Flavour compounds in spray-dired skim milk powder, J. Agric. Food Chem. 42 (1994) 984-988.

[19] Stevenson R.L., Chen X.D., A study of volatile trapping in spray dried whey protein concentrate by crushing and/or vacumming, and detection by solid-phase microextraction/gas chromatography/mass spectroscopy, Food Res. Int. 29 (1996) 495-504.

[20] Vazquez-Landaverde P.A., Velasquez G., Torres J.A., Qian M.C., Quantitaive determination of thermally derived off-flavor compounds in milk using solid-phase microextraction and gaz chromatography, J. Dairy Sci. (2005) 3764-3772.

[21] Whetstine M.E.C., Croissant A.E., Drake M.A., Characteristization of dried whey protein concentrate and isolate flavor, J. Dairy Sci. 88 (2005) 3826-3839.

[22] Wright J.M., Whetstine M.E.C., Miracle R.E., Drake M., Characterization of acabbage off-flavor in whey protein isolate, J. Food Sci. 71 (2006) 86-90. 